\title{
The Effect of Flexible Working Arrangements on Work Engagement of Online Motorcycle Taxi Drivers
}

\author{
Umi Farida ${ }^{1}$ \\ ${ }^{1}$ Department of Psychology, Universitas Negeri Yogyakarta, \\ J1. Colombo No. Depok, Sleman, Yogyakarta 55281, Indonesia \\ ${ }^{1}$ umiffarida90@gmail.com
}

\begin{abstract}
This study aims to determine the effect of flexible working arrangements on the work engagement of online motorcycle taxi drivers. This research used a quantitative approach and included ex-post facto research. This study used 297 online motorcycle taxi drivers in the Special Region of Yogyakarta. The data collection technique used a measuring instrument in the form of a psychological scale that has been tested for validity and reliability. The psychological scale is the work engagement scale with Cronbach's Alpha 0.881 and the flexible working arrangements scale with Cronbach's Alpha 0.910. The data analysis technique to test the research hypothesis used a simple regression test. Based on the data analysis, the regression coefficient was 1.636 and sig. $0.000<0.005$ with $\mathrm{R}$ Square $=0.671$. These results indicate an effect of flexible working arrangements to work engagement positively and significantly by $67,1 \%$.
\end{abstract}

Keywords: work engagement; flexible working arrangements; online motorcycle taxi drivers

\section{Introduction}

Industrial revolution 4.0 has led to an increase in the human economy due to the rapid development of digital technology. The rapid development of technology makes the world run fast and instantaneous. According to the World Economic Forum, Indonesia is predicted to be one of the countries affected in various sectors due to these changes. One of them is the employment sector, where the types of work become diverse with different work systems. One of these jobs is an online motorcycle taxi driver. Jobs as online motorcycle taxi drivers did not previously exist in Indonesia until they finally appeared in 2015. Based on the International Labor Organization (ILO) report on employment in Indonesia in 2017, there will be a change in the type of work from agriculture to jobs that focus on services or services in the next few years. Online motorcycle taxis are one of the new jobs that have emerged due to technological developments. Online motorcycle taxis serve customers by offering services to deliver passengers and goods connected using an online-based application.

Jobs as online motorcycle taxi drivers are in demand by many people because of their convenience. However, on the other hand, work as an online motorcycle taxi driver also has a high risk because of working in the field. For example, the risk of having an accident on the road or a conflict with motorcycle taxi drivers who refuses to join the online motorcycle taxi driver platform. The increase in the number of drivers every year also makes the competition between drivers more stringent. These are a stressor for the driver itself.

In contrast to these conditions, a preliminary study in 2019 which measured work engagement of online motorcycle taxi drivers showed that the work engagement of online motorcycle taxi drivers was high. Work engagement is a positive appreciation of work characterised by vigour, dedication, 
and absorption (Schaufeli, Salanova, Gonzales-Roma, and Bakker, 2002). Therefore, work engagement is essential for companies and employees, such as online motorcycle taxi drivers. Online motorcycle taxi drivers have not been fully engaged due to the heavy work risks.

Apart from the serious risks, work as an online motorcycle taxi driver has its charm. One of them is a flexible work system. However, nowadays, online motorcycle taxi drivers feel trapped in this flexible work system. Technically, online motorcycle taxi drivers will find it easier to modify their working hours and places. However, instead of working flexibly, drivers must work all day to chase points or bonuses. A flexible work system should make it easier for drivers to adjust the time and place of work. However, in practice, the drivers work harder even with working hours of more than 8 hours. In addition, sometimes you have to pick up to a location that is quite far from the driver's location, which makes work no longer flexible. This certainly has an impact on the psychological condition and work performance of online motorcycle taxi drivers.

These problems began to arise due to the high public interest in work as online motorcycle taxi drivers, thus making the number of online motorcycle taxi drivers uncontrollable. The number of online motorcycle taxi drivers is continuously increasing and even encouraging the government to limit online motorcycle taxi drivers' number to maintain this online transportation service business ecosystem (money.kompas.com). The increase in the number of drivers has resulted in tighter competition between drivers and a decrease in the income of online motorcycle taxi drivers. This shows the complexity of the problems related to a flexible work system.

On the other hand, Sadida \& Febriani (2016) and Abednego (2015) mention that a flexible work system can also provide positive values and overcome several employee problems. According to Ali
(2019), flexible working arrangements can increase employee engagement through the leader-member exchange. Ugargol \& Patrick (2018) also explain that flexible working arrangements are positively related to IT employee engagement.

Based on the description above, it can be said that there are differences between the results of the research and field conditions related to flexible working arrangements and work engagement of online motorcycle taxi drivers as described. This topic is also interesting because the job as an online motorcycle taxi driver is currently in great demand by the public.

Therefore, this study was conducted to discuss the effect of flexible working arrangements on work engagement on online motorcycle taxi drivers. The results of this study are expected to be considered for companies and drivers to regulate work systems that support drivers to become more engaged in their work.

\section{Methods}

This study uses a quantitative approach with the ex-post facto. According to Ibrahim et al. (2018), it is stated that expost facto research is research that aims to determine causal relationships without any manipulation or treatment of independent variables by researchers. This research was conducted in the city of Yogyakarta. This research began on November 7, 2019. Data collection was carried out from May 1 June 30, 2020.

\section{Research Subject}

The subject of this research is an online motorcycle taxi driver operating in the city of Yogyakarta. The population of this study is not known with certainty. Therefore, the required sample is obtained through the Cohran formula, and the required number of 384 subjects is obtained. 
Research Procedure

The data collection procedure was carried out using a purposive sampling technique with the condition that the respondent was an active online motorcycle taxi driver in the city of Yogyakarta. Furthermore, the data was collected using a questionnaire distributed online via a google form. The questionnaires were distributed through WhatsApp and Facebook groups containing online motorcycle taxi drivers active in Yogyakarta. After the data is collected, then the item selection is carried out. According to Azwar (2018), item choice is based on the total item correlation value $<0.3$. After the item selection is made and the selected item has been determined, it is continued with data collection using a questionnaire after the trial.

\section{Data, Instruments, and Data Collection Techniques}

The data collection technique used in this research is using a psychological scale. Psychological scale is a data collection technique in which items do not directly reveal the measured attribute but reveal behavioural indicators of the attribute in question (Azwar, 2016). This study uses four alternative answers from a modified Likert-type scale.

The data collection instruments used in this study were the work engagement scale (Schaeufeli \& Bakker, 2002) and the flexible working arrangements scale (Selby \& Wilson, 2001).

The validity used in this study is content validity through expert judgment, meanwhile, for reliability using Cronbach's Alpha statistical test. The results obtained are the work engagement scale of 0.881 and the flexible working arrangements scale of 0.910 .

\section{Data Analysis}

The data analysis technique used in this research is descriptive analysis to categorise the levels of the variables $\mathrm{X}$ and Y. Furthermore, the prerequisite tests are normality and linearity tests. Hypothesis testing was carried out using simple linear regression analysis.

\section{Findings}

The object of this research is an online motorcycle taxi driver operating in Yogyakarta. Online motorcycle taxi drivers work under the auspices of online motorcycle taxi service providers. However, these online motorcycle taxi drivers, independently from online motorcycle taxi associations or associations, facilitate communication between drivers. Online motorcycle taxi drivers work using android-based applications such as Grab, Gojek, Maxim and so on through their respective smartphones. The extensive area coverage makes the respondents of this study have various characteristics.

Based on the data obtained, online motorcycle taxi drivers willing to become respondents are 297 respondents. This is because not all online motorcycle taxi drivers are willing to become respondents voluntarily. Most of the respondents belong to the age group of $20-29$ years, with $52 \%$ of the total respondents. $99 \%$ of the respondents are male, dominated by drivers from high school graduates/equivalent. The majority have worked for more than two years, and $65 \%$ of online motorcycle taxi drivers make this job their primary job. The application used the most is grab then gojek, and the rest are other applications.

\section{Data Description}

Based on the descriptive analysis, the data on work engagement variables can be seen, which can be seen in Figure 1. 


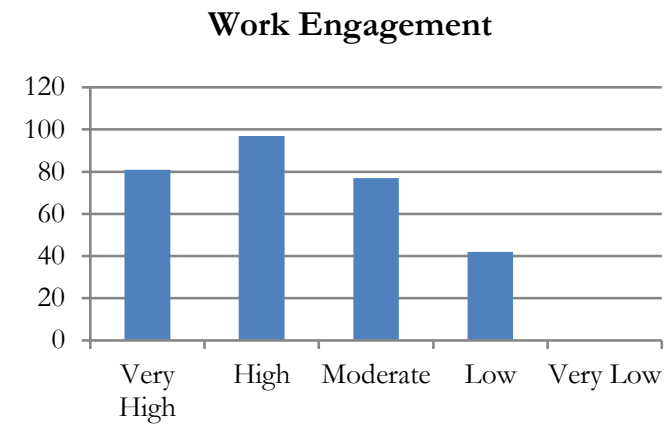

Figure 1. Work engagement variable graph

Based on Figure 1. It can be seen that the level of work engagement of online motorcycle taxi drivers tends to be high. Furthermore, the description related to the variable of flexible working arrangements can be seen in Figure 2 .

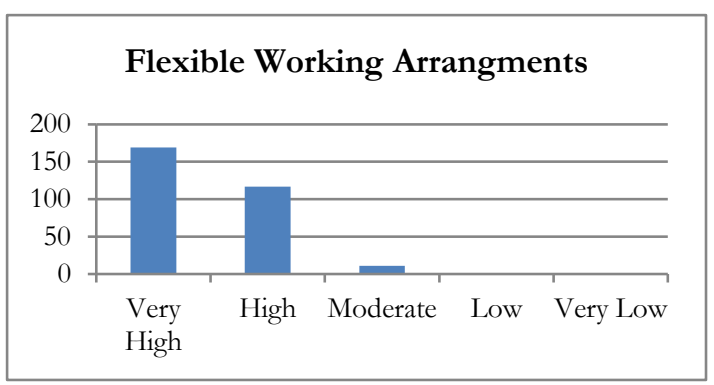

Figure 1. Variable Graph Flexible working arrangements

Based on Figure 2. It can be seen that the level of flexible working arrangements tends to be very high.

\section{Data Analysis}

The prerequisite test in this study consists of a normality test and a linearity test. The results indicate normal data distribution asymp. sig $>0,05$ and linear relationship between $\mathrm{X}$ and $\mathrm{Y}$ variables (deviation from linearity $\mathrm{p}>.05$ )

Hypothesis testing in this study uses simple linear regression analysis consisting of a simple linear regression equation, the results of the $t$ statistic test and the coefficient of determination. The simple linear regression equation is as follows.
$\mathrm{Y}=34,122+1,636 \mathrm{X}$

Based on this equation, it can be seen that the constant value of work engagement is 34,122 . Meanwhile, it is known that for every $1 \%$ addition of flexible working arrangements $(\mathrm{X})$, work engagement $(Y)$ will increase by 1.636 . the value of the regression coefficient is positive, so it can be interpreted that there is a positive effect of flexible working arrangements on work engagement.

Table 3. Statistical Test Results t

\begin{tabular}{ccc}
\hline & $\mathbf{t}$ & Sig. \\
\hline Constant & 21,522 & 0,000 \\
\hline Fwas & 24,526 & 0,000
\end{tabular}

The regression analysis results above show that the significance value (Sig.) of 0.000 is smaller than 0.05 . So it can be concluded that there is an effect of flexible working arrangements (X) on work engagement $(\mathrm{Y})$.

Table 4. Coefficient of Determination

R
\[ 819^{a} \]
The results of the coefficient of
determination or R Square obtained 0.671.
This figure means that the variable, flexible
working arrangements (X), affects the work
engagement variable by $67.1 \%$. Meanwhile,
the remaining $32.9 \%$ are influenced by
other variables outside this regression
equation or other variables not examined.

\section{Discussion}

Work engagement is a condition felt by employees where employees feel they have positive feelings and trust in the company to create high work enthusiasm. Based on the data obtained, no online 
motorcycle taxi drivers have low or very low work engagement. It can be said that the work engagement of the drivers is already high and can be maintained. This is also supported by the results of this study, where most of the respondents have worked for more than two years. This shows that the drivers feel comfortable as online motorcycle taxi drivers. In addition, $65 \%$ of the respondents make this job their primary job. Most of the respondents are known to be productive, where the productive age has greater work demands. This can encourage drivers to be engaged because the work of online motorcycle taxi drivers is their primary job.

Flexible working arrangements are conditions in which employees find it easy to arrange their place and work schedule flexibly (Selby \& Wilson, 2001). Jobs as online motorcycle taxi drivers require drivers to work in the field and be ready at any time. Therefore, having flexible working arrangements is very helpful for online motorcycle taxi drivers. It can be seen from the results of this study that when viewed by age, most of the drivers are the millennial generation. Interestingly, the millennial generation is interested in work with high flexible working arrangements, one of which is as an online motorcycle taxi driver.

According to Selby \& Wilson (2001), flexible working arrangements are only suitable for highly disciplined, resultoriented employees, can manage time and work and like challenges. Many millennials are interested in working as online motorcycle taxi drivers because of flexible working arrangements. As an online motorcycle taxi driver, flexible working arrangements can help drivers balance work and personal life. Many make online motorcycle taxi drivers an option, especially for people who want flexibility in their work, one of which is the millennial generation. Therefore, half of the respondents in this study were in the 20 year-old age group.
The results of the prerequisite tests and hypothesis testing that have been carried out in this study indicate an effect of flexible working arrangements on work engagement on online motorcycle taxi drivers. From the results of this study, it is known that flexible working arrangements positively affect work engagement. This is evidenced by the results of a simple linear regression analysis, where the significance value (A.Symp) is less than 0.05 $(0.000<0.05)$. Therefore, it can be concluded that $\mathrm{Ha}$ is accepted and $\mathrm{HO}$ is rejected, which means that flexible working arrangements influence work engagement. Based on the results of this study, it is stated that flexible working arrangements have an effect of $67.1 \%$ on work engagement. Therefore, flexible working arrangements have a significant role in the work engagement of online motorcycle taxi drivers.

It is essential to implement flexible working arrangements to increase online motorcycle taxi drivers (Pri, 2018). Companies as management holders need to pay attention to this, that flexible working arrangements have a significant role in increasing work engagement. Looking at the effect of flexible working arrangements on work engagement, we can say that flexible working arrangement are effective for online motorcycle taxi drivers. According to Kelliher (2009), the freedom companies give to drivers will help drivers work according to their abilities. That way, drivers can work more productively, enthusiastically, and in prime condition. This condition is increasing day by day, which will make drivers become engaged in the work they do (Sadida \& Febriani, 2016).

\section{Limitions}

During the research process, there were several limitations that the researchers encountered. Researchers have difficulty controlling respondents who fill out the psychological scale are online motorcycle taxi drivers. This is because the 
psychological scale is distributed online, so there is a possibility that non-drivers will also fill in the scale.

\section{Conclusion}

Based on the research results, it can be concluded that flexible working arrangements positively affect work engagement on online motorcycle taxi drivers. Therefore, the higher the flexible working arrangements of the online motorcycle taxi drivers, the higher the work engagement of the online motorcycle taxi drivers. This is evidenced by the regression analysis results, which shows a significance value (A.Symp) less than 0.05 . With an $\mathrm{R}$ Square value of 0.671 , flexible working arrangements have an effect of $67.1 \%$ on work engagement on online motorcycle taxi drivers.

\section{References}

Abednego, K. S., Gunawan, E. A., \& Widjaja, D. C. (2015). Pengaruh Schedule Flexibility Terhadap Turnover Intention Dengan Kepuasan Kerja Sebagai Variabel Perantara Di Surabaya Plaza Hotel. Jurnal Hospitality dan Manajemen Jasa, 3(1), 12-25.

Albion, M. J. (2004). A Measure Of Attitudes Towards Flexible Work Options. In Australian Journal Of Management, 29(1), 33-45.

Ali Alqarni, S. Y. (2016). Quality Of Work Life As A Predictor Of Work engagement Among The Teaching Faculty At King Abdulaziz University. In International Journal Of Humanities And Social Science, 6(8), 823. Www.Ijhssnet.Com

Anderson, D., \& Kelliher, C. (2009). Flexible Working And Engagement: The Importance Of Choice. Strategic HR Review, 8(2), 13-18. Doi.10.1108/14754390910937530
Ayu, D. R., Maarif, M. S., \& Sukmawati, A. (2015). Pengaruh job demands, job resources dan personal resources terhadap work engagement.Jurnal Aplikasi Bisnis dan Manajemen (JABM), 1(1), 12-25.

Azwar, S. (2016). Reliabilitas Dan Validitas Aitem. Buletin Psikologi. Doi.10.22146/Bpsi.13381

Bakker, A. B., \& Albrecht, S. (2018). Work engagement: Current Trends. In Career Development International, 23(1), 4-11. Emerald Group Publishing Ltd. Doi.10.1108/CDI-11-2017-0207

Bengngu, A., Amtiran, P. Y., \& Fanggidae, R. E. (2019). Impact of Part Time, Flextime and Reward on Productivity (Case Study on Grab Online Transportation Partners in Kupang City). In International Conference on Tourism, Economics, Accounting, Management, and Social Science (TEAMS 2018). Atlantis Press.

Carlson, D. S., Grzywacz, J. G., \& Michele Kacmar, K. (2010). The Relationship Of Schedule Flexibility And Outcomes Via The Work Family Interface. Journal of Managerial Psychology, 25(4), 330-355. Doi.10.1108/02683941011035278

Cochran, W. G., \& William, G. (1977). Sampling Techniques. New York: John Wiley\& Sons.

Damayanti, S. A. S. (2017). Transportasi Berbasis Aplikasi Online: Go-Jek Sebagai Sarana Transportasi Masyarakat Kota Surabaya (Doctoral dissertation, Universitas Airlangga).

Dantes, Nyoman. (2012). Metode Penelitian. Yogyakarta: CV Andi Offset.

Davis, K. \& Newstorm, J.W. (2007). Organisational Behavior: Human Behavior at Work. New York: McGraw Hill Education. 
Emmerink, R. H. M., \& Van Beek, P. (1997). Empirical Analysis Of Work Schedule Flexibility: Implications For Road Pricing And Driver Information Systems. In Urban Studies, 34(2), 112120.

Gozhali, Imam. (2018). Aplikasi Analisis Multivariat dengan SPSS. Semarang: UNDIP Press

Ibrahim. (2018). Metodologi Penelitian Kualitatif: Panduan Penelitian dan Contoh Proposal. Bandung: Alfabeta.

Irawati, E. (2019). Welcoming Flexible Working Arrangement For Civil Servant. In Jurnal Analis Kebijakan. 2(1), 23-31.

Juvonen, M. (2019). Flexible Working and Employee Engagement. Metropolia University of Applied Science.

Kahn, W. A. 1990. Psychological conditions of personal engagement and disangagement at work. Academy of Management Journal, 33(4), 692-724.

Kelliher, C., \& Anderson, D. (2009). Flexible Working in Organisations: The Perspective of Co-Workers. Paper at International Industrial Relations Association World Congress, Sydney.

Kuok, A. C., \& Taormina, R. J. (2017). Work engagement. Evolution of the concept and a new inventory. Psychological Thought, 10(2), 262-287.

Maifanda, N., Muhammad, ), Slamet, R., Negeri, P., Jurusan, B., Bisnis, M., Akuntansi, S., Jl, M., \& Yani, A. (2019). Pengaruh Gaji, Jam Kerja Fleksibel dan Stres Kerja terhadap Kinerja Karyawan pada Perusahaan di Kota Batam. Journal of Applied Managerial Accounting, 3(1), 25-34.

Mathis, R. L., \& Jackson, J. H. (2008). Human Resource Management (12th ed). Thomson South-Western.

Kemenhub. (2019). Peraturan Menteri Perbubungan No. 12, Tabun 2019, tentang Pelindungan Keselamatan Pengguna
Sepeda Motor yang Digunakan untuk Kepentingan Masyarakat.

Pri, R., \& Zamralita, Z. (2018). Gambaran Work engagement Pada Karyawan Di Pt $\mathrm{Eg}$ (Manufacturing Industry). Jurnal Muara Ilmu Sosial, Humaniora, Dan Seni, 1(2), 295-303.

Robbins, S. P., \& Judge, T. A. (2015). Perilaku Organisasi (Organizational Behavior) (16th ed.). Jakarta: McGraw Hill dan Salemba Empat.

Sadida, N., \& Febriani, Z. (2016). Mengikat Karyawan Dengan Telecommuting (Studi Keterikatan Kerja Karyawan Telecommuting). Jurnal

Psikogenesis, 4(1), 114-125.

Selby, C., Wilson, F., Korte, W., Millard, J., \& Carter, W. (2001). Flexible Working Handbook, Sofia, Bulgaria: Virtech.Ltd.

Setiawati, F. A., Mardapi, D., \& Azwar, S. (2013). Penskalaan teori klasik instrumen multiple intelligences tipe Thurstone dan Likert. Jurnal Penelitian dan Evaluasi Pendidikan, 17(2), 259274. Doi.10.21831/Pep.V17i2.1699

Simamora, T. V., Mustika, M. D., \& Sjabadhyni, B. (2019). Effects Of Flexible Work Arrangements On Ethical Decision Making: Job Satisfaction As A Mediator. Jurnal Psikologi Talenta, 4(2), 113-121.

Ugargol, J. D., \& Patrick, H. A. (2018). The relationship of workplace flexibility to employee engagement among information technology employees in India. South Asian Journal of Human Resources Management, 5(1), 40-55.

Yustrianthe, R. H. (2008). Pengaruh flexible work arrangement terhadap role conflict, role overload, reduced personal accomplishment, job satisfaction dan intention to stay. Jurnal bisnis dan akuntansi, 10(3), 127138. 
Widhiarso, W. (2016). Peranan Butir Unfavorabel Dalam Menghasilkan Dimensi Baru Dalam Pengukuran Psikologi. Jurnal Psikologi Perseptual, 1(1), 40-52.

Wright, P. M. \& Nishii, L. H. (2007). Strategic HRM and organisational behavior: Integrating multiple levels of analysis (CAHRS Working Paper). Ithaca, NY: Cornell University, School of Industrial and Labor Relations, Center for Advanced Human Resource Studies. 